\title{
Factors Affecting Wheat Production in Balochistan Province of Pakistan
}

\author{
Jumo Khan Bajkani ${ }^{1}$, Khalil Ahmed ${ }^{2}$, Muhammad Afzal ${ }^{3}$, Ali Raza Jamali ${ }^{4}$, \\ Illahi Bux Bhatti ${ }^{5}$, Sohail Iqbal ${ }^{6}$ \\ ${ }^{1}$ Senior Scientific Officer, SSRI, PARC, Sariab Quetta, \\ ${ }^{2}$ Lecturar, Horticulture Department, Balochistan Agriculture College Ballely, Quetta, \\ ${ }^{3}$ Director/Principle Scientific Officer, SSRI, PARC, Sariab Quetta, \\ ${ }^{4}$ Director General/CSO, BARDC, PARC, Quetta, \\ ${ }^{5}$ Senior Scientific Officer, NSTHRI, PARC, Thatta, Sindh, \\ ${ }^{6}$ Research Officer, Department of Plant Protection, ARI, Quetta
}

\begin{abstract}
This paper describes to the major factors responsible for decline in wheat productivity in the Balochistan during 2012-13. It involved gathering of data from primary as well as secondary sources, particularly on cropping systems, input use, management practices and other related issues. Survey was conducted in the upper zone (Loralai, Killa Saifullah) and plain zone (Nasirabad, Jaffarabad). Total 80 respondents were interviewed from both zones. The production system was found to follow traditional practices resulting in low production as compared to the potential yield. Major of causes of low yield identified were less rain and water shortage. Wheat variety Inqlab was dominant in the study area and 43.7 percent growers planted this variety during 2012-13. During 2012-13 wheat growers applied only phosphorus $37.5 \mathrm{~kg} / \mathrm{ac}$ and there was no much variation in application of chemical fertilizer during 2011-12. The area under wheat during 2012-13 showed a decline of 0.04\% in the study area. Among growers 57.5\% reported high price of chemical fertilizer and $25 \%$ reported non-availability of high yielding varieties seed, responsible for decline in wheat average.
\end{abstract}

Key Words: Triticum aestivum, Facor affecting, Productivity, Balochistan

\section{Introduction:}

Agricultural is the backbone of Pakistan's economy. About $68 \%$ of the population is engaged in farming directly or indirectly through production, processing and distribution of major agricultural commodities. Agriculture contributes about 21 percent of our Gross Domestic Product (GDP), provides livelihood to about 68 percent people living in rural areas and employs about 45 percent of the total national labour force. The agriculture sector is the major contributor in the overall export earnings of Pakistan. The share of Food Group alone in the total export of Pakistan for the year 2010-11 stood at 17.5 percent (Agril. Stat. of Pakistan, 2010-11) [1].

Wheat (Triticum aestivum L.) is an important crop from food -security perspective and is the largest grain crop of the country grown under almost all ecological zones of the country. It is largely grown in Punjab 75 and Sindh 13 percent (Agril. Stat. of Pakistan, 2010-11) [1], provinces in Pakistan and cultivated in Rabi season under both irrigated and rainfed conditions. The performance of wheat crop affects the overall growth rate, import bill of economy and nutritional standard of the people. Government has increased the procurement price from Rs 1050 to Rs. 1200 (Government of Pakistan, 2012-13) [2]. Prices of wheat in neighboring countries were also very high compared with the price prevailing in the domestic market. Consequently, the price differential encouraged unscrupulous elements to enter into hoarding and smuggling, causing domestic price to surge at unprecedented level.

Wheat contributes 10.1 percent to the value added in agriculture and 2.2 percent to GDP and export of wheat declined considerably (53.3 percent) due to unfavorable international prices during 2012-13 as compared to 2011-12(Government of Pakistan, 2012-13) [2]. The decline in wheat export is also attributed to higher increase in domestic cost of production due to high input prices like fertilizer, insecticides, transportation cost and power cost resulting its non competitiveness in the international market. Therefore import of wheat remained a regular phenomenon and import 2685 thousand tones of wheat during 2008-09 (Agril. Stat. of Pakistan, 2010-11) [1]. Area under wheat increased to 8693 thousand hectares in 2012-13, from 8650 thousand hectares showing an increased of 0.5 percent over last year's area. The production stood at 24.2 million tonnes during 2012-13, against the target of 25.5 millions tonnes which is 5.1 percent decrease while an increase of 3.2 percent over the last year production of 23.5 million tonnes has been witnessed. The yield per hectare in 2012- 
13 stood at $2787(\mathrm{Kgs} / \mathrm{Hec})$ posted a positive growth of 2.7 percent as compared to negative 4.2 percent growth last year (Government of Pakistan, 2012-13) [2].

Balochistan province was covering wheat crop area 388.416 thousand hectares and production was 842.734 thousand tones in the year 2011-12. In same year area, production and yield was increased as compared to 2010-11 (Government of Ballochistan, 2011-12) [3], due to favorable temperature and timely sowing. Wheat yield in the province is well below the potential and the province is deficit in wheat production. The Balochistan contributes overall high area and production was 4.80 and 4.14 percent respectively, 2007-08 (Agril. Stat. of Pakistan, 2010-11)[1], as compared other years (Table 1). Therefore this study was assigned by the Social Sciences Research Institute, Pakistan Agricultural Research Council, at ARI Quetta to identify the major factors responsible for lower wheat production and to suggest measure to sustain the wheat productivity in province. The specific objectives are: to identify the differences in wheat production practices as compared with previous year, the factors responsible for lower wheat productivity in Balochistan and to suggest an appropriate strategies to sustain wheat productivity in the province.

Table 1: Area and Production Percent contribution of Wheat Crop in Pakistan and Balochistan

\begin{tabular}{|l|l|l|l|l|l|l|}
\hline \multirow{2}{*}{ Year } & Pakistan & Balochistan & \multicolumn{2}{l}{$\begin{array}{l}\text { Contribution } \\
\text { Balochistan }\end{array}$} \\
\cline { 2 - 8 } & $\begin{array}{l}\text { Area } \\
\text { '000'Ha }\end{array}$ & $\begin{array}{l}\text { Production } \\
\text { '000 t' }\end{array}$ & $\begin{array}{l}\text { Area } \\
\text { '000'Ha }\end{array}$ & $\begin{array}{l}\text { Production } \\
\text { '000 t' }\end{array}$ & Area & Production \\
\hline $2001-02$ & 8057.5 & 18226.5 & 333.6 & 640.6 & 4.14 & 3.51 \\
\hline $2002-03$ & 8033.9 & 19183.3 & 340.8 & 654.7 & 4.24 & 3.41 \\
\hline $2003-04$ & 8216.2 & 19499.8 & 340.9 & 663.4 & 4.15 & 3.40 \\
\hline $2004-05$ & 8358.0 & 21612.3 & 343.1 & 637.6 & 4.11 & 2.95 \\
\hline $2005-06$ & 8447.9 & 21276.8 & 310 & 649.9 & 3.67 & 3.05 \\
\hline $2006-07$ & 8578.2 & 23294.7 & 408.9 & 872.1 & 4.77 & 3.74 \\
\hline $2007-08$ & 8549.8 & 20958.8 & 410.6 & 868.6 & 4.80 & 4.14 \\
\hline $2008-09$ & 9046.0 & 24032.9 & 408.9 & 868.2 & 4.52 & 3.61 \\
\hline $2009-10$ & 9131.6 & 23310.8 & 367.5 & 536.2 & 4.02 & 2.30 \\
\hline $2010-11$ & 8900.7 & 25213.8 & 340.8 & 729.1 & 3.83 & 2.89 \\
\hline
\end{tabular}

Source: (Agri. Stat. of Pakistan, 2010-11)

\section{Research Methodology}

For this study both primary and secondary data were collected to describe and analyze the wheat production system and to quantifying the level of input and other related issues. Secondary data were collected on different variables like area, production and yield of wheat. Other variables were collected from various sources including, Agriculture Statistics of Pakistan, Agriculture Statistics of Balochistan and Agriculture extension. The study was undertaken in plain and upper zones of Balochistan, from plain zone two districts i.e. Nasirabad and Jaffarabad and from upper zone, Loralai and Qilla Saifullah districts were selected. From each district 20 respondents were interviewed personally hence, total sample size was 80 . A questionnaire was developed and pretested before conducting the formal survey. The questionnaire covered information relating to the socioeconomic characteristics of the respondents like land tenure, farm size, source of irrigation and other related variables. It also included questions related to total wheat area in 2011-12 and 2012-13, total area, out of that area sown before $30^{\text {th }}$ November of each year, input use, production practices and physical productivity. The respondents were also asked the reason for increase/decrease wheat production in current year. Farmers were interviewed personally at their farms. Before starting the interview, the researchers explained the purpose of the research and assured the respondents that all information would be confidential and be used for research purpose only. A comparative analysis was made in order to investigate the various factors responsible for lower wheat yield in the target area of Balochistan during 2012-13. These techniques included: descriptive statistics, frequency distribution, and regression.

\section{Linear regression}

The simple linear regression may be defined as a way to describe the relationship between two variables by calculating a best-fitting straight line on a graph. The line averages or summarizes the relationship. The result is a regression line expressed in a regression equation. The general formula for the regression model is shown as follows:

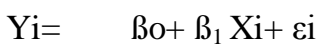

where $\mathrm{Yi}=$ response variable

$B_{0}=$ intercept regression

$\beta_{1}=$ regression coefficient

$\varepsilon i=$ error term which further normal distribution with mean variance.

Multiple regression is a statistical technique in which more than one independent variables are involved in order to predict the dependent variable. Multiple regression analysis is also highly useful in experimental 
situation where the experimenter can control the independent variables. The technique uses a number of variables to predict some unknown variable. The basic formulas is given as follows

$\mathrm{Yi}=\beta_{\mathrm{o}}+\beta_{1} \mathrm{X}_{1}+\beta_{2} \mathrm{X}_{2}+\beta_{3} \mathrm{X}_{3}+\ldots \ldots+\beta \mathrm{p}-1 \mathrm{Xi}, \mathrm{p}-\mathrm{i}+\varepsilon \mathrm{i}$

where

$\beta$ o is $\mathrm{Y}$ intercept,

$\beta_{1}, \beta_{2}, \beta_{3}, \beta \mathrm{p}$ are the parameters of the regression equation,

$\varepsilon i=$ random error in $y$ for observation $i$.

\section{Results and Discussions}

The main focus of this section is on the results of the survey. This section is organized into four sub-sections.

1) This section deals with the socioeconomic characteristic of the sample farmers.

2) This section is devoted to the description of farmers' wheat production practices during 2011-12 and 201213.

3) This section analyses are given of the factors contributing to increase/decrease wheat yield during 2012-13.

4) Farmers suggestions for sustaining next year wheat are presented in this section.

\subsection{Socioeconomic Characteristics of the Sample Respondents \\ 3.1.1Farm Size}

It is important to examine how resources are managed, and resulting impact on productivity and sustainability. The empirical literature indicated that, small farmers have an advantage in labor supervision over large farmers. Therefore, the quantity of labor inputs is likely to be higher on small farms. Second, small farmers have restricted access to modern input, and this can hold back their productivity, third, small and large farmers may differ in their attitude to risk and uncertainty. The large farmers may be more willing and able to carry greater risk. Results showed that 45 percent of respondents had less than 12.5 acres, followed by 25 percent having more than $12.5-25$ acres. The 30 percent farmers' were from above 25 acres category. High small farm size was found in upper zone 29(72.5\%) and medium farm size in plain zone 19(47.5\%) in table 2.

Table 2. Operational Land Holding of Selected Growers

\begin{tabular}{|l|l|l|l|l|}
\hline \multirow{2}{*}{ Farm size groups } & Zone wise $(\%)$ & \multirow{2}{*}{ All $(\boldsymbol{\%})$} & $\begin{array}{l}\text { Average farm size } \\
\text { (acres) }\end{array}$ \\
\cline { 2 - 5 } & Upper zone & Plain zone & & 11.6 \\
\hline Small (< 12.5 acre) & 72.5 & 17.5 & 45.0 & 23.9 \\
\hline Medium (>12.5-25 acre) & 15 & 35.0 & 25.0 & 162.89 \\
\hline Large (>25 acre) & 12.5 & 47.5 & 30.0 & 60.06 \\
\hline All & 50.0 & 50.0 & 100.0 & . \\
\hline
\end{tabular}

Note: Figures in parentheses are percentages.

\subsubsection{Area Under Wheat Crop}

Total landholding of sampled respondents in upper zone was recorded as 6538 acres

out of which 785 acres were under wheat during 2011-12 and in 2012-13, it was 861 acres. Whereas in plain zone total landholding of sample respondents was 20068 acres out of which 4020 acres were under wheat during 2012-13 while in 2011-12 it was 3946 acres. It is clear from the results that there were -0.04 percent decrease in area under wheat during 2012-13 as compared to last year 2011-12 (table 3).

Table 3. Total Area under Wheat by the Sample Respondents

\begin{tabular}{|l|l|l|l|l|}
\hline Zone & $\begin{array}{l}\text { Total Area } \\
\text { (acres) }\end{array}$ & $\begin{array}{l}\text { Area under Wheat } \\
\mathbf{2 0 1 2 - 1 3}\end{array}$ & Area under Wheat 2011-12 & $\begin{array}{l}\text { \% Increase/ } \\
\text { Decrease (2012-13) }\end{array}$ \\
\hline Upper Zone & 6538 & 785 & 861 & -8.9 \\
\hline Plain Zone & 20068 & 4020 & 3946 & 1.9 \\
\hline Total & 26606 & 4805 & 4807 & -0.04 \\
\hline
\end{tabular}

Source: Survey data, 2012-13

\subsubsection{Wheat Varietal Distribution}

Seed varieties play an important role for high production in agriculture crop. The rate of adoption of high yielding varieties determines the speed with which any farming community takes benefits of the efforts of breeders. Pakistan is one of the countries where varietal replacement has been generally very slow although farmers quickly adopted semi-dwarf wheat varieties at the time of the Green Revolution in the late 1960s (Byerlee, 1993)[4]. The many farmers did not know about new recommended wheat varieties. The major varieties planted were Inqlab, Bakhar, Zardana and Cham- 6 cultivated by $41.85,21.5 \% 11.2 \%$ and $7.5 \%$ farmers respectively during both years. About $71.25 \%$ of the farmers planted only one variety of wheat.

\subsubsection{Seed Source}


Quality seed is one of the important crop inputs for obtaining high yield. Farmers have various sources of seed such as own farm produced seed, input/seed dealers, seed corporation, fellow farmers and research stations. Information about farmers' seed sources describes the role of various seed distribution agencies in transferring good quality seed to the farmers and has important implications for the policy makers in smooth delivery of this key input. Survey results revealed that use of own seed is increased and still very common among the farmers. Majority 67.5\% used their own seed during 2012-13 followed by 59 percent during 2011-12.

\subsubsection{Planting Period}

It is a well-established fact that planting time has important implication on wheat yield. It significantly affects seed germination, number of tillers, number of grains per spike and eventually the grain yield. At farmers' fields, wheat planting time is determined by various factors such as type of kharif crops planted before wheat, incidence of insects or diseases on kharif crops, soil types, occurrence of rainfall (specially in rainfed belts) and methods of wheat plantation. For obtaining optimum yield, wheat plantation should be completed during the month of November. Data collected during the survey from upper and plain zones indicated that on an average 53.5 percent of the total area was planted till $30^{\text {th }}$, November during 2012-13 while 56 percent wheat area was planted same date during 2011-12. Qureshi, et al, 2001[5], reported that 72.1 percent of the total wheat area was planted till $30^{\text {th }}$ November during 1999-2000 in irrigated Balochistan.

Table 4. Planting Period of Wheat by Zone Wise

\begin{tabular}{|l|l|l|l|}
\hline Planting time & $\begin{array}{l}\text { Upper zone } \\
\text { (Percent) }\end{array}$ & $\begin{array}{l}\text { Plain zone } \\
\text { (Percent) }\end{array}$ & Average \\
\hline $\mathbf{2 0 1 2 - 1 3}$ & 53 & 4 & 28.5 \\
\hline Before 15 November & 37 & 70 & 53.5 \\
\hline Between 15-30 November & 10 & 26 & 18 \\
\hline After 30 November & \multicolumn{3}{|l}{} \\
\hline $\mathbf{2 0 1 1 - 1 2}$ & 47 & 9 & 28 \\
\hline Before 15 November & 46 & 66 & 56 \\
\hline Between 15-30 November & 7 & 25 & 16 \\
\hline After 30 November & \multicolumn{2}{|l|}{} \\
\hline
\end{tabular}

Source: Survey data, 2012-13

\subsubsection{Sowing Methods}

The most common method of wheat planting found was broadcasting. Majority 86.3 percent farmers planted their wheat crop by this method, and 13.7 percent of the farmers reported drill/line method during 201213. Whereas 91.2 percent farmers planted their wheat crop through broadcasting method and 8.8 percent planted drill/line sowing during 2011-12.

\subsubsection{Land preparation}

Proper land preparation is an initial task for crop cultivation. A good land preparation is necessary for proper and rapid growth of the crop. Since most of the wheat area fall in rotation with kharif crop, therefore, the use of various type of ploughs other than cultivator are necessary for good land preparation. Majority (57 percent) of the sampled farmers used 3 Plough for land preparation, which included 1 mould board and 2 cultivators with planking. None of the sample farmers applied farmyard manure (FYM) to wheat field during both the seasons under study area. Reasons of none FYM application to wheat field are mostly soil of Balochistan is fertile, plain zone (Nasirabad and Jaffarabad) farmers were not livestock holders, upper zone (Loralai and Killa Saifullah) farmers applied FYM to orchard and vegetables field, farmers have no trend of FYM application to wheat crop and mostly farmers were used dung's for fuel.

\subsubsection{Seed Rate}

Result showed that overall; seed rate for early-planted wheat varieties was used $55 \mathrm{~kg} /$ acre during 2012-13 followed by $49 \mathrm{~kg} / \mathrm{acre}$ during 2011-12. While in late season overall $61 \mathrm{~kg}$ was used during 2012-13 as compared to $51.7 \mathrm{~kg} / \mathrm{acre}$ during 2011-12.

\subsubsection{Fertilizer Application}

Fertilizer application is essential to obtain optimum yield of wheat. The farmers were applying only phosphorus at the rate of $37.5 \mathrm{~kg}$ as basal dressing during 2012-13. As top dressing farmers were applying only Nitrogen at the rate of $45.5 \mathrm{~kg}$ per acre. While in 2011-12 farmers applied $18.5 \mathrm{~kg}$ per acre phosphorus and $6 \mathrm{~kg}$ per acre of Nitrogen. 


\subsubsection{Weed Infestation}

It is a recognized fact that weeds are the serious yield-limiting factor in the Pakistan. Weeds compete with crop plants for nutrients, water and sunlight. The extent of yield loss varies from farm-to-farm depending upon the types and strength of weeds. It was observed that over all 10.5 percent area was seriously infested with weeds during 2012-13. The little increasing trend was observed among the growers to control weeds through weedicide during 2012-13 than the previous year 2011-12. Manual weed control method was exercised relatively in more proportion in weed infested wheat acreage during both seasons.

\subsubsection{Irrigation}

In Balochistan farmers have different sources of irrigation such as canal, tube well and Karaz etc. The total water requirement of wheat crop including soaking dose is about 21 acre-inches. There are 6 physiological stages of the crop growth, which include; crown root stage, tillering stage, booting stage, anthesis stage, milky stage and dough stage (Khushk, et al, 2001)[6]. The interval between two physiological growth stages averages to 21 days. However, first irrigation is necessary to be given at crown root stage, which usually comes three weeks after sowing. The survey results showed that all the farms in plain zone were using canal irrigation and no supplement irrigation was given by tube well or any other sources. While, in upper zone farmers were using tube well and Karaz as source of irrigation. During the both years on average wheat growers applied two canal irrigations in plain zone and 5-7 tube well irrigations to wheat crop in the upper zone.

\subsubsection{Wheat Yield Loses}

Wheat crop is prone to risk of drought/moisture stress, cold spell/frost and rust etc. During the present survey, an attempt was made to quantify wheat yield losses due to these factors. During 2012-13 in overall 15.4 percent area was affected due to drought/moisture stress causing $1.9 \mathrm{mds}$ per acre yield losses. The intensity was higher in plain zone where 18.3 percent wheat area was affected due to drought/moisture stress causing a yield loss of $2.5 \mathrm{mds}$ per acre. Losses in wheat yield due to rust disease were recorded $0.5 \mathrm{mds}$ per acre.

\subsubsection{Harvesting}

Harvesting is the most labor-intensive operations in wheat production. Wheat is harvested manually starting from April to May in both cropping zones, with family and hired labor. Majority of the growers 77 percent used their family labor and remaining 23 percent used hired labor. The average harvesting charges were Rs. 1415 per acre. Harvesting is done by both male and female labor.

\subsubsection{Wheat Yield and average total production}

High yield can be achieved by adopting scientific technologies like use of certified seeds, application of recommended doses of fertilizers, etc (Khushk, et al, 2001)[6]. Table 5 indicated that in overall, growers received 23mds/ acre during 2012-13 and it was 23.05 mds/acre during 2011-12. The wheat production in upper zone and plain zone was 389.9 mds and 1829.3 mds respectively, during 2012-13. While in 2011-12 total product6ion of wheat in upper land and plain zones was 536.2 and 1792 mds respectively. It is clear that the overall wheat production was decreased 5 percent during 2012-13.

Table 5. Average Wheat Yield by Zone Wise

\begin{tabular}{|l|l|l|l|}
\hline \multicolumn{2}{|l|}{ Upper Land } & \multicolumn{1}{l|}{ Plain Zone } & All \\
\hline $\mathbf{2 0 1 2 - 1 3}$ & 389.9 & 1829.3 & 1109.6 \\
\hline Average Production (mds) & 23.1 & 23.0 & 23.0 \\
\hline Average Yield (mds/acre) & 536.2 & 1792 & 1164 \\
\hline $\mathbf{2 0 1 1 - 1 2}$ & 26.4 & 19.7 & 23.05 \\
\hline Average Production (mds) &
\end{tabular}

Source: Survey data, 2012-13

\subsubsection{Reason of Change in Wheat Area}

The main factors motivating farmers to bring more area under wheat were the high support price of wheat. Result reveals that majority 57 and 53 percent sample respondents of plain and upper zone reported high price of wheat as the principal reason for increasing wheat area. Whereas 57.5 and 35 percent respondents reported that due to high price of fertilizer they could not increase their wheat area. While 47.5 and 43 percent sampled respondents of upper and plain zone reported that due to limited land they kept same area under wheat presented in table 6 . 
Table 6. Reasons of Change in Wheat Acreage

\begin{tabular}{|l|l|l|}
\hline Reasons for change & Upper Zone(Percent) & Plain Zone (Percent) \\
\hline Increase & \multicolumn{2}{|l|}{} \\
\hline High Price of wheat & 53 & 57 \\
\hline No other Alternate crop during Rabi season & - & 9 \\
\hline Availability of high yielding variety seed & 18 & 21 \\
\hline More Wheat for Home Consumption & 16 & 8 \\
\hline Others & 13 & 5 \\
\hline Decrease & \multicolumn{2}{|l|}{} \\
\hline High price of fertilizer & 35 & 57.5 \\
\hline Shortage of water & 25 & 10 \\
\hline Non-availability of high yielding variety seed & 5 & 25 \\
\hline More loadsheding & 30 & - \\
\hline High price of diesel & 5 & 7.5 \\
\hline Same/No change & \multicolumn{2}{|l|}{} \\
\hline High price of fertilizer & 30 & 42 \\
\hline Shortage of water & 17.5 & - \\
\hline Low production & 5 & 15 \\
\hline Limited land & 57.5 & 43 \\
\hline Source: Survey & \multicolumn{2}{|l}{} \\
\hline
\end{tabular}

Source: Survey data, 2012-13

\subsubsection{Factors Contributing in Increase/Decrease Wheat Yield}

Farmers' perception about the increase in wheat yield and the reason behind such change was investigated. Overall, 27.5 percent reported increased use of improved seed as major factor for high yield. Second main reason reported by the farmers was the availability of irrigation water. Whereas, fertilizer and timely sowing were also considered major factors for increase in wheat yield. The farmers' perceptions about the decrease in wheat yield were also recorded and 22.5 percent reported decrease in wheat yield due to shortage of irrigation water. The farmer's for decrease of wheat yield reported high cool temperature, low rainfall, loadsheding and weed problem (Table 7).

Table 7. Farmers' Perceptions About Major Factors Contributing to Increase/Decrease in Wheat Yield During 2012-13

\begin{tabular}{|l|l|l|l|}
\hline Reasons & Upper Land & Plain Zone & All \\
\hline Reason for Increase Wheat Yield & \multicolumn{2}{|l|}{} \\
\hline Improved seed & 27.5 & 20 & 23.7 \\
\hline Timely sowing & 20 & 12.5 & 16 \\
\hline Use of fertilizer & 25 & 30 & 27.5 \\
\hline Good weather & - & 15 & 7.5 \\
\hline Water availability & 27.5 & 22.5 & 25 \\
\hline Reason for Decrease Wheat Yield & 10 & \multicolumn{3}{l|}{} \\
\hline Water shortage & 25 & 35 & 22.5 \\
\hline High cold & 32.5 & 12.5 & 18.7 \\
\hline Low rainfall & 10 & - & 16 \\
\hline Weeds problem & 22.5 & 21.5 & 15.7 \\
\hline Loadsheding & - & 21 & 16 \\
\hline $\begin{array}{l}\text { Late sowing due to water logging in rice } \\
\text { field }\end{array}$ & & & 10.5 \\
\hline
\end{tabular}

Source: Survey data, 2012-13

\subsubsection{Regression Analysis}

To determine the key factors responsible for low wheat yield in Balochistan during the year 2012-13. A multiple regression model was used to estimate the contribution of each factor in wheat production. The model was estimated in linear form, so the value of the parameters showed the individual contribution of each factors in production. The dependent variable was estimated as total wheat production (mds) in 2012-13. The hypothesize contributing in wheat yields, were as follows:

Planting date (positive if it is sown before $30^{\text {th }}$ November)

No. of irrigations (Positive)

Nitrogen fertilizer (Positive)

Phosphorous Fertilizer (Positive) 
Wheat varieties sown (Positive if it is recommended)

Stepwise analysis was carried out to select a best-fit model, taking the entire variables, which were considered to be responsible for wheat production in Balochistan. On the basis of probability criteria, the best model included the following variables (i) wheat area sown before November $30^{\text {th }}$ (ii) wheat planted between 15-30 November, (iii) Total DAP, (iv) Total Urea (v) No. of irrigation.

Table 8. Contribution of Factors in Wheat Yield: Regression Estimates

\begin{tabular}{|l|l|l|l|}
\hline \multirow{2}{*}{ Factors } & Standardized Coefficients & \multirow{2}{*}{ t. } & \multirow{2}{*}{ Sig. } \\
\cline { 2 - 3 } Constant & Beta & -2.665 & .009 \\
\hline Wheat planted before 15th November & & -.436 & .664 \\
\hline Wheat area planted 15 - 30 November & -.045 & .481 & .632 \\
\hline Total quantity of DAP & .051 & -1.073 & $.287^{* *}$ \\
\hline Total quantity of Urea & $-.107^{* *}$ & 2.273 & $.026^{* *}$ \\
\hline Total no. of canal irrigations & $.228^{* *}$ & 3.973 & $.000^{* * *}$ \\
\hline Total no. of tube well irrigations & $1.121^{* * *}$ & 4.685 & $.000^{* * *}$ \\
\hline
\end{tabular}

Dependent Variable: wheat yield mds/ac *** =Highly Significant $* *=$ Significant

$\mathrm{R}-$ Square $=.308$. R -SQ Adjusted $=.252$

Wheat yield $=\mathbf{- 2 4 . 3 1 5}-0.045$ (Wheat planted before 15th November) +0.051 (planted $15-30$ November) +0.107 (quantity of DAP) + 0.228 (quantity of Urea) + 1.121 (no. of canal irrigations) +1.292 (no. of tube well irrigations)

Parameters included in table 8 shows the positive sign indicated that they have positive contribution in wheat yield. R. Square of the model was 0.308 , which show that these variables have contributed about $30 \%$ in the wheat yield. On the statistical criteria, the main factors, No of irrigations and use of fertilizer strongly correlated with yield. The evidence collected during the survey also supported the results obtained from the regression analysis. Results show that majority 85 percent of the wheat growers has completed timely planting while 15 percent wheat planted after recommended period.

Likewise, numbers of irrigation is also important and have positive impact on wheat yield. Results also indicated that use of urea is also having positive impact on wheat.

\section{Conclusion And Recommendations}

The main purpose of this study was to conduct detail investigation to identify the major factors responsible for decline in wheat productivity in the Balochistan during 2012-13. It involved gathering of data from primary as well as secondary sources, particularly on input use, management practices and other related issues. Survey was conducted in the upper and plain zones. Loralai and Killa Saifullah districts were selected from upper zone, Nasirabad and Jaffarabad districts from plain zone. Total 80 respondents were interviewed from both zones. The production system was found to follow traditional practices resulting in low production as compared to the potential yield. Causes of low yield identified were lack of knowledge of improved variety, inadequate use of fertilizer and weedicide application. Wheat variety Inqlab was dominant in the study area and 43.7 percent growers planted this variety during 2012-13. Wheat growers applied only phosphorus $37.5 \mathrm{~kg} / \mathrm{ac}$ and none of the grower applied Nitrogen as basal dressing and there was no much variation in application of chemical fertilizer during 2011-12. Results revealed that there are number of factors involved in changing of wheat acreage. High price of fertilizer was reported by $57.5 \%$ growers and $25 \%$ reported non-availability of high yielding varieties seed. Wheat production during 2012-13 decreased up to 5 percent as compared 2011-12.

Wheat growers have to adopt better management practices and seek to adopt scientific recommendations from local and available sources such as, research stations, progressive growers and extension agents. Particularly, they require timely planting of wheat and appropriate use of fertilizer and weedicide. Nonavailability of improved, disease - free, certified seed of high yielding wheat varieties is the main constraint in large-scale wheat production in Balochistan. Involvement of privates sector is highly recommended to provide improved certified seed to the wheat growers. The government must play an important role to communicate trainings to the farmers through agriculture extension department. The farmers have no knowledge about use of fertilizers, because of un-balanced use of fertilizers creates hardpan in the soil. Improper applications of fertilizer decrease the soil productivity. The balanced uses of fertilizers increase the productivity of the soil, and help in the more production of the soil. There was lack of agricultural machinery for land leveling. The machinery for land leveling will help farmers to bring more land under cultivation. Land leveling reduces the water losses and more area can be brought under cultivation. Credit facility must be provided to the wheat farmers for the wheat inputs with out interest, because the wheat growers will encourage them to timely purchase the inputs and increase the production of wheat. Wheat growers normally purchase inputs from commission agents in the high costly in absence of credit facility. This is highly recommended that in future 
similar studies on other crops must be carried out to recognize the factors affecting area and production of that exacting crop in Balochistan province.

\section{Acknowledgement}

Apart from the efforts of myself, the success of any research project depends largely on the encouragement and guidelines of many others. The author wishes to thank several people. I would like to express my deepest appreciation to all those who provided me the possibility to complete this research paper. Much special gratitude goes to my senior scientists whose contribution in stimulating suggestions and encouragement helped me in writing this research publication/report.

Furthermore I would also like to acknowledge and special thanks goes to my team member Ms Iram Hanif, Office Secretary who help me to assemble the analysis work and gave valuable suggestion about the task. Last but not least, many thanks go to the head of the Institute, Mr Ali Raza Jamali whose have invested his full effort in guiding the team in achieving the goal and useful comment and remarks in developing research paper. I have to appreciate the guidance given by other fellow colleagues as well.

I take this opportunity to express my gratitude to the people who have been instrumental in the successful completion of this research project. The guidance and support received from all the members who contributed and who are contributing to this project, was vital for the success of the project. I am grateful for their constant support and help.

\section{References:}

[1]. Government of Pakistan (2010-11). Agricultural Statistics of Pakistan. Federal Bureau of Statistics, Statistics Division, Islamabad

[2]. Government of Pakistan (2012-13), Economic Survey of Pakistan. Economic Advisor's Wing. Finance Division Islamabad.

[3]. Government of Balochistan (2011-12). Agricultural Statistics of Balochistan. Agricultural Statistics Wing, Agriculture (Extension) Department Balochistan, Sariab Road, Quetta.

[4]. Byerlee, D. 1993, Technical change and returns to wheat breeding research in Pakistan Punjab in the post green revolution period", the Pakistan Development Review, 32(1), pp: 69-86.

[5]. Qureshi, A.H, M.Iqbal, N.A.Shah and M.Afzal 2001. Determinant of Wheat Productivity in Irrigated Balochistan. Research Report of AERU, ARI, Sariab Quetta, PP 7-8.

[6]. Khushk, A.M, I.Lashari, J.A.Lund, M.A. Memon and U. Shar, 2001. Factor Responsible for Higher Wheat Yield in Sindh. Research Report of AERU, ARI, Tandojam. 